\title{
Effect of Uterine Fibroid on Women's Health Related Quality of Life
}

\author{
Huda Ebrahiem Elsaied ${ }^{1}$, Sanaa Ali Nour Eldin ${ }^{2}$, Amany Hamed Gad ${ }^{3}$ \& Heba Al-Kotb Mohamed ${ }^{4}$. \\ 1. M.Sc. Nursing, Faculty of Nursing- Suez Canal University, Egypt. \\ 2. Professor of Obstetric \& Gynecological Nursing-Faculty of Nursing Zagazig University, Egypt. \\ 3. Assistant Professor of Obstetric \& Gynecological Nursing-Faculty of Nursing Zagazig University, Egypt. \\ 4. Assistant Professor Family and Community Health Nursing Faculty of Nursing Suez Canal University, Egypt.
}

\begin{abstract}
Aim: The present study aimed to assess the effect of uterine fibroid on their women's life. Sample: 285 females with UF were recruited for estimating average health related quality of life (HRQOL). Setting: the study was conducted at Gynecological outpatient clinic at Zagazig University Hospital. Design: the study applied adescriptive design was utilized to conduct this study in which two tools were used for data collection. Special structured questionnaire was designed to entail data related to socio demographic and the second tool included scale of health related quality of life (HRQOL). Results: the majority of the sample (87.4\%) was $\geq 40$ years, with mean score of $47.32 \pm 5.939$, the majority $(81.8 \%)$ of studied woman had severity of symptoms and studied woman had negative impact on HRQOL concern, control, energy, activities, self-conscious and sexual function. Conclusion: We can conclude that fibroids impact negatively on women's health and quality of life. Recommendation: Based on the findings of the present study it was recommended that, women should be provided with simple information (through brochures and booklets) that can consist of health education about uterine fibroid. Replication of the study on nurses to improve their awareness, health practices and beliefs regarding the prevention and early detection of uterine fibroid, which will be reflected in improving women's awareness, health practices and beliefs.
\end{abstract}

\section{Keywords: Uterine Fibroid (UF) \& Health Related Quality Of Life (HRQOL).}

\section{Introduction}

Uterine fibroids or uterine leiomyoma (UL) are the most common disease of reproductive-age women. They are the commonest benign tumors of the smooth muscle of the uterus taking origin in the myometrium, and are typically round well-circumscribed masses. They are usually multiple, and can range in size from a few millimeters to massive growths of $20 \mathrm{~cm}$ diameter and more. The etiology is largely unknown, but they are estrogen-and progesterone-dependent tumors, very rare before menarche and frequently regress in size after menopause. UF aren't associated with an increased risk of uterine cancer (Sparic et al., 2016).

Although fibroids are often asymptomatic, UL can cause excessive menstrual bleeding, pelvic pain, and other symptoms that seriously affect a woman's quality of life. Symptomatic UL may require medical or surgical intervention and increased medical utilization. Excessive vaginal blood loss can lead to severe anemia which can even be life-threatening, yet some patients do not recognize the severity of the problem (Angelos et al., 2015). UF place a large economic on the women who suffer from them, and on the health systems and societies in which they live. Symptoms may lead to significant loss of working time, or career aspirations (Borah et al., 2014).

Health related quality of life (HRQOL) among women with UF was significantly impacted by UF- related symptoms. Greater impact was observed as the number and severity of symptoms increased (Soliman et al., 2017). Most women reported fears associated with their fibroids, including being afraid that the fibroids will grow and that they will need a hysterectomy, as well as fears regarding relationships, sexual function, body image, loss of control and hopelessness. Almost two-thirds of women were concerned about missed days from work due to their symptoms, and 24 percent of employed respondents felt that their symptoms prevented them from reaching their career potential. Women with extreme pain from fibroids may lose contact with friends and coworkers because of their inability to go to work or even just leave their bed for an extended period of time (Mayo Clinic, 2019).

Uterine leiomyoma has a critical impact on patients' lives; health care providers should focus on guiding them to recovery. With the specific evaluation of the quality of life related to a specific condition, the professional should be able to measure the impact of the disease. Symptoms that negatively affect a woman's daily life are a primary indication for treatment. Standard treatments of LM symptoms include myomectomy, hysterectomy, uterine artery embolization, and pharmacologic treatments that reduce symptoms. 


\section{Significance of the study}

Fibroids have a considerable impact on women's quality of life as well as their productivity. In Zimmermann et al., (2012) survey of more than 21.000 women from 8 different countries, including 2500 from Canada, symptoms had a negative impact on sexual life (43\%), performance at work (28\%), relationship and family (27\%). This last parameter was the object of fewer researches.

\section{Aim of the study}

The aim of the current study was to assess the effect of uterine fibroid on their women's life.

This aim has been achieved through the following objective

Describe and evaluate the effect of uterine fibroid on women's health related quality of life.

\section{Subjects \& Methods}

Research design

The present study is Prospective descriptive design.

\section{Study setting}

The study was conducted at Gynecological outpatient clinic of Zagazig university hospital

\section{Study subjects}

The study population consisted of patients having uterine fibroids and attending the study settings. The sample consisted of 285 women diagnosed as having uterine fibroid since one year or more for this study according to the following:

\section{Inclusion Criteria}

1- Women diagnosed with uterine fibroid since one year or more.

2- Women's age ranged between 17- 55.

\section{Tools of data collection}

Data were collected using two tools

Tool I: A structured interview questionnaire

It was developed by the researcher to collect the necessary data for the study. It composed of three parts:

Part 1: Socio-demographic characteristics of the studied subjects as; age, sex, educational level, occupation and residence

Part 2: Obstetric history such as gravida and para.

Part 3: Gynecological history included history of previous gynecological diseases as well as abnormal uterine bleeding, dysmenorrhea, urinary tract infection, infertility, endometriosis, polycystic ovary syndrome and previous D\&C.

Tool II: Scale of HRQOL is divided into two sections:

Section 1: Symptom severity: the first eight questions these questions use a 5- point Likert-type scale ranging from 1 (not at all) to 5 (a very great deal). The data obtained from this scale are at the ordinal level. The participants received points based upon their response as indicated: 1 point for not at all, 2 points for a little bit, 3 points for somewhat, 4 points for a great deal and 5 points for a very great deal. This section has eight questions total; therefore, scores for this section ranged from 8 to 40 (with scores closer to 40 reflecting greater perceived symptom severity) (Coyne et al., 2012).

\section{Section 2: HRQOL scale}

These questions are evaluates HRQOL and consists of 27 questions. This section is broken down into six subsections: concern (Questions 9, 15, 22, 28, 32), activities (Questions 10, 11, 13, 19, 20, 27, 29), energy/mood (Questions 12, 17, 23, 24, 25, 31, 35), control (Questions 14, 16, 26, 30, 34), self-conscious (Questions, 18, 21, 33), and sexual function (Questions 36 and 37).

The subscales are used to assess feelings and experiences regarding the impact of uterine fibroids symptoms on various areas of each participant's life. These questions use a 5 point Likert scale ranging from 1 (none of the time) to 5 (all of the time). The participants received points based upon their response as indicated: 1 point for none of the time, 2 points for a little bit of the time, 3 points for some of the time, 4 points for most of the time and 5 points for all of the time.

\section{Scoring system}

- According to severity of symptoms

Low score $<50 \%$

Moderate score $50 \%$ - $<75 \%$

Severe score $\geq 75 \%$

- According to HRQOL

Poor score $<50 \%$

Moderate score $50 \%-<75 \%$

High score $\geq 75 \%$

The preparatory phase:

The objectives were derived from the assessed women's problem. In addition about health related quality of life among women's using textbooks, web sites, and articles in the scientific periodicals and journals.

\section{Content validity}

The tools were reviewed by experts from the departments of obstetrics and gynecological Nursing, at the Faculty of Nursing, Zagazig University and Suez Canal University. These experts assessed the tools for clarity, relevance, application and comprehensiveness. This constituted the content validation of tools. All recommended modifications were applied.

\section{Pilot study}

It was performed to evaluate the questionnair validity and reliability. A pilot study was carried out on 28 women from the study setting $10 \%$ of the calculated 
sample for main study they were selected randomly from Gynecological outpatient clinic in Zagazig university hospital. The purposes of pilot were to test the questions for any obscurity, and to assess the practicability and feasibility of using the structured interview questionnaire. It also helped the researcher to determine the time needed for filling out the forms. The tools were finalized after doing necessary modifications according to the pilot study results. The pilot subjects were not included later in the main study sample.

\section{Field work}

Once permission was granted to proceed with the study, the researcher started to prepare a schedule for collecting the data. Participants were interviewed by the researcher who introduced herself and explained the aim of the study briefly, and reassured them that information obtained is strictly confidential and would not be used for any purposes other than research. The fieldwork was executed in 9 months. It extended from the first of January 2018 to the end of September 2018. The researcher collected data daily during the whole week according to the inclusion criteria. Concerning the descriptive part of this research, the researcher used a structured interview questionnaire tool and HRQOL scale

\section{Administrative and ethical considerations}

An official permission was granted by submission of an official letter from the Faculty of Nursing of Suez Canal University to the responsible authorities of the study setting to obtain their permission for data collection, explained the study aim to the women and the importance of the study and its procedures, and asked for his cooperation. A verbal agreement for participation of the informants was taken. Participants was given the opportunity to refuse the participation, and they was notified that they could withdraw at any stage of the data collection interviews; also they were assured that the information would be confidential and used for the research purpose only. The researcher assured maintaining anonymity and confidentiality of subjects' data. The researcher phone number and all possible communicating methods were identified to the participants to return at any time for any explanation.

\section{Statistical analysis}

Data entry and statistical analysis were done using SPSS 20 statistical software package. Data were presented using descriptive statistics in the form of frequencies and percentages for qualitative variables, and means and standard deviations for quantitative variables. When normal distribution of the data could not be assumed, the non-parametric Mann-Whitney test was used instead. Qualitative categorical variables were compared using chi-square test. Whenever the expected values in one or more of the cells in a $2 \times 2$ tables was less than 5 , Fisher exact test was used instead. In larger than $2 \times 2$ cross-tables, no test could be applied whenever the expected value in $10 \%$ or more of the cells was less than 5 . Statistical significance was considered at $p$-value $<0.05$.

\section{Results}

Table (1): Distribution of studied women according to their socio demographic characteristics $(\mathbf{n}=285)$.

\begin{tabular}{|c|c|c|c|}
\hline \multicolumn{2}{|c|}{ Socio-demographic data } & No & $\%$ \\
\hline \multirow{3}{*}{ Age in years } & $17-30$ & 36 & 12.6 \\
\hline & $40-$ & 104 & 36.4 \\
\hline & $50-55$ & 145 & 51.0 \\
\hline & Mean Std. Deviation & \multicolumn{2}{|c|}{$47.32 \pm 5.939$} \\
\hline \multirow{5}{*}{ Education } & Illiterate & 16 & 5.6 \\
\hline & Read and write & 38 & 13.3 \\
\hline & Primary school & 35 & 12.5 \\
\hline & Secondary school & 108 & 37.8 \\
\hline & University & 88 & 30.8 \\
\hline \multirow{2}{*}{ Occupation } & House wife & 178 & 62.5 \\
\hline & Working & 107 & 37.5 \\
\hline \multirow{2}{*}{ Residence } & Rural & 149 & 52.3 \\
\hline & Urban & 136 & 47.7 \\
\hline \multirow{4}{*}{ Marital status } & Single & 9 & 3.1 \\
\hline & Married & 233 & 81.8 \\
\hline & Divorced & 18 & 6.3 \\
\hline & Widow & 25 & 8.8 \\
\hline
\end{tabular}


Table (2): Distribution of studied women according to Obstetric history $(\mathrm{n}=285)$.

\begin{tabular}{|c|c|c|c|}
\hline \multicolumn{2}{|c|}{ Obstetric history } & No & $\%$ \\
\hline \multirow{2}{*}{ Normal menstrual cycle } & No & 197 & 69.1 \\
\hline & Yes & 88 & 30.9 \\
\hline \multirow{5}{*}{ Abnormal menstrual cycle } & Menorrhagia & 102 & 70.8 \\
\hline & Metrorragia & 63 & 43.8 \\
\hline & Polymenorrhea & 22 & 15.3 \\
\hline & Polymenorrhagia & 32 & 22.2 \\
\hline & Post-menopausal bleeding & 25 & 17.4 \\
\hline \multirow{3}{*}{ Parity } & Nulliparous & 22 & 7.7 \\
\hline & $1-3$ & 128 & 44.9 \\
\hline & $4+$ & 135 & 47.4 \\
\hline \multicolumn{2}{|c|}{ Mean Std. Deviation } & \multicolumn{2}{|c|}{$2.29 \pm .757$} \\
\hline \multirow{8}{*}{ Gynecological history } & None & 111 & 38.9 \\
\hline & Abnormal uterine bleeding & 100 & 35.1 \\
\hline & Dysmenorrhea & 88 & 30.9 \\
\hline & Urinary tract infection & 25 & 8.8 \\
\hline & Infertility & 12 & 4.2 \\
\hline & Endometriosis & 9 & 3.2 \\
\hline & Polycystic ovary syndrome & 18 & 6.3 \\
\hline & History of D\&C & 57 & 20.0 \\
\hline
\end{tabular}

() More than one answer

Table (3): Distribution of studied women according to history of UF disease $(n=285)$.

\begin{tabular}{|c|c|c|c|}
\hline \multicolumn{2}{|r|}{ Disease data } & No & $\%$ \\
\hline \multirow{2}{*}{$\begin{array}{l}\text { Time to seek treatment } \\
\quad \text { in yeas }\end{array}$} & $<3$ & 126 & 44.2 \\
\hline & $>3+$ & 159 & 55.8 \\
\hline & Mean Std. Deviation & \multicolumn{2}{|c|}{$3.49 \pm 1.498$} \\
\hline \multirow{2}{*}{ Delayed in having treatment } & No & 160 & 56.1 \\
\hline & Yes & 125 & 43.9 \\
\hline \multirow{7}{*}{ Cause of delayed treatment } & Refuse husband & 8 & 6.4 \\
\hline & Afraid of treatment and operation & 58 & 46.4 \\
\hline & Unavailability of health services & 9 & 7.2 \\
\hline & Financial problem & 37 & 29.6 \\
\hline & Lack of knowledge about disease and treatment & 11 & 8.8 \\
\hline & Hope for pregnancy & 29 & 23.2 \\
\hline & Emotional factor & 40 & 32.0 \\
\hline \multirow{4}{*}{$\begin{array}{l}\text { Duration of delay in yeas } \\
\qquad(n=125)\end{array}$} & 1 & 35 & 28.0 \\
\hline & 2 & 46 & 36.8 \\
\hline & 3 & 25 & 20.0 \\
\hline & $4+$ & 19 & 15.2 \\
\hline & Mean Std. Deviation & \multicolumn{2}{|c|}{$2.22 \pm 1.023$} \\
\hline \multirow{7}{*}{ Complications of delay } & Emotional problem & 43 & 34.4 \\
\hline & Sexual problem & 22 & 17.6 \\
\hline & Excessive bleeding & 80 & 64.0 \\
\hline & Anemia & 21 & 16.8 \\
\hline & Abortion & 14 & 11.2 \\
\hline & Blood transfusion & 12 & 9.6 \\
\hline & Infertility & 13 & 10.4 \\
\hline
\end{tabular}

(-) More than one answer 


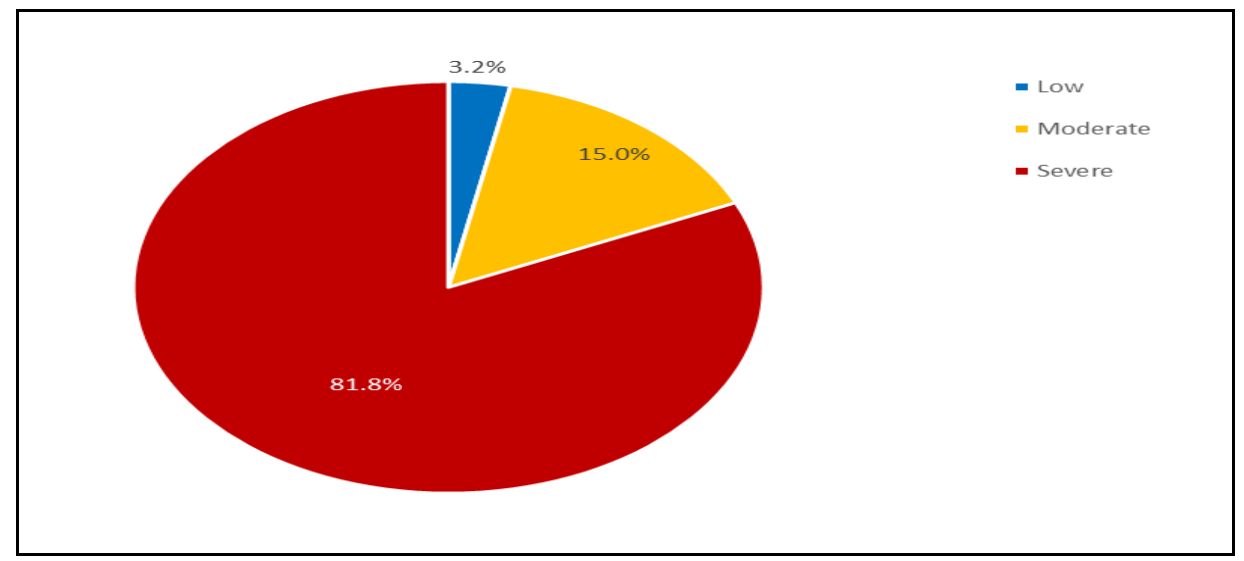

Figure (1): Distribution of studied women according to severity of symptoms $(n=285)$.

Table (4): Distribution of studied women according to severity of symptoms $(n=285)$.

\begin{tabular}{|l|c|c|c|c|c|c|c|c|c|c|}
\hline \multirow{2}{*}{\multicolumn{1}{|c|}{ Items }} & \multicolumn{2}{c|}{ Not at all } & \multicolumn{2}{c|}{ A little bit } & \multicolumn{2}{c|}{ Some-what } & \multicolumn{2}{c|}{ A great deal } & \multicolumn{2}{c|}{ Very great deal } \\
\cline { 2 - 12 } & $\mathbf{N}$ & $\%$ & $\mathbf{N}$ & $\%$ & $\mathbf{N}$ & $\%$ & $\mathbf{N}$ & $\%$ & $\mathbf{N}$ & $\%$ \\
\hline $\begin{array}{l}\text { Heavy bleeding during } \\
\text { menstrual period }\end{array}$ & 0 & 0.0 & 0 & 0.0 & 20 & 7.0 & 0 & 0.0 & 265 & 93.0 \\
\hline $\begin{array}{l}\text { Passing blood clots during } \\
\text { menstrual period }\end{array}$ & 14 & 4.9 & 5 & 1.8 & 25 & 8.8 & 0 & 0.0 & 241 & 84.6 \\
\hline $\begin{array}{l}\text { Fluctuation in the duration of } \\
\text { menstrual period compared to } \\
\text { previous cycle }\end{array}$ & 6 & 2.1 & 0 & 0.0 & 17 & 6.0 & 2 & 0.7 & 260 & 91.2 \\
\hline $\begin{array}{l}\text { Fluctuation in the length of } \\
\text { monthly cycle compared to } \\
\text { previous cycles }\end{array}$ & 14 & 4.9 & 1 & 0.4 & 20 & 7.0 & 7 & 2.5 & 243 & 85.3 \\
\hline $\begin{array}{l}\text { Feeling tightness or pressure } \\
\text { in pelvic area }\end{array}$ & 11 & 3.9 & 2 & 0.7 & 44 & 15.4 & 2 & 0.7 & 226 & 79.3 \\
\hline $\begin{array}{l}\text { Frequent urination during } \\
\text { daytime hours }\end{array}$ & 21 & 7.4 & 8 & 2.8 & 37 & 13.0 & 3 & 1.1 & 216 & 75.8 \\
\hline Frequent nighttime urination & 36 & 12.6 & 4 & 1.4 & 53 & 18.6 & 5 & 1.8 & 187 & 65.6 \\
\hline Feeling fatigued & 32 & 11.2 & 2 & 0.7 & 64 & 22.5 & 0 & 0.0 & 187 & 65.6 \\
\hline
\end{tabular}

Table (5): Distribution of studied women according to Health related quality of life concern $(n=285)$

\begin{tabular}{|c|c|c|c|c|c|c|c|c|c|c|}
\hline \multirow[t]{2}{*}{ Items } & \multicolumn{2}{|c|}{$\begin{array}{l}\text { None of the } \\
\text { time }\end{array}$} & \multicolumn{2}{|c|}{$\begin{array}{l}\text { A little of } \\
\text { the time }\end{array}$} & \multicolumn{2}{|c|}{$\begin{array}{l}\text { Some of } \\
\text { the time }\end{array}$} & \multicolumn{2}{|c|}{$\begin{array}{l}\text { Most of } \\
\text { the time }\end{array}$} & \multicolumn{2}{|c|}{$\begin{array}{l}\text { All of the } \\
\text { time }\end{array}$} \\
\hline & $\mathbf{N}$ & $\%$ & $\mathbf{N}$ & $\%$ & $\mathbf{N}$ & $\%$ & $\mathbf{N}$ & $\%$ & $\mathbf{N}$ & $\%$ \\
\hline $\begin{array}{l}\text { Made you feel anxious about the } \\
\text { unpredictable onset or duration of } \\
\text { periods? }\end{array}$ & 10 & 3.5 & 0 & 0.0 & 20 & 7.0 & 5 & 1.8 & 250 & 87.7 \\
\hline $\begin{array}{l}\text { Made you concerned about soiling } \\
\text { underclothes? }\end{array}$ & 10 & 3.5 & 0 & 0.0 & 17 & 6.0 & 7 & 2.5 & 251 & 88.1 \\
\hline $\begin{array}{l}\text { Made you concerned about soiling } \\
\text { bed linen? }\end{array}$ & 3 & 1.1 & 2 & 0.7 & 26 & 9.1 & 9 & 3.2 & 245 & 86.0 \\
\hline $\begin{array}{l}\text { Made you feel inconvenienced } \\
\text { about always carrying extra pads, } \\
\text { tampons, and clothing to avoid } \\
\text { accidents? }\end{array}$ & 2 & 0.7 & 1 & 0.4 & 26 & 9.1 & 10 & 3.5 & 246 & 86.3 \\
\hline $\begin{array}{l}\text { Made you concerned about soiling } \\
\text { outer clothes? }\end{array}$ & 7 & 2.5 & 0 & 0.0 & 25 & 8.8 & 4 & 1.4 & 249 & 87.4 \\
\hline
\end{tabular}


Table (6): Distribution of studied women according to Health related quality of life activities $(n=285)$.

\begin{tabular}{|l|c|c|c|c|c|c|c|c|c|c|}
\hline \multirow{2}{*}{\multicolumn{1}{|c|}{ Items }} & \multicolumn{2}{c|}{$\begin{array}{c}\text { None of the } \\
\text { time }\end{array}$} & \multicolumn{2}{c|}{$\begin{array}{c}\text { A little of } \\
\text { the time }\end{array}$} & \multicolumn{2}{c|}{$\begin{array}{c}\text { Some of the } \\
\text { time }\end{array}$} & \multicolumn{2}{c|}{$\begin{array}{c}\text { Most of the } \\
\text { time }\end{array}$} & \multicolumn{2}{c|}{ All of the time } \\
\cline { 2 - 13 } & $\mathbf{N}$ & \% & $\mathbf{N}$ & $\%$ & N & \% & N & \% & N & $\%$ \\
\hline $\begin{array}{l}\text { Made you anxious about } \\
\text { traveling? }\end{array}$ & 21 & 7.4 & 0 & 0.0 & 21 & 7.4 & 4 & 1.4 & 239 & 83.9 \\
\hline $\begin{array}{l}\text { Interfered with your } \\
\text { physical activities? }\end{array}$ & 9 & 3.2 & 0 & 0.0 & 27 & 9.5 & 6 & 2.1 & 243 & 85.3 \\
\hline $\begin{array}{l}\text { Made you decrease time } \\
\text { you spent on exercise? }\end{array}$ & 12 & 4.2 & 0 & 0.0 & 22 & 7.7 & 4 & 1.4 & 247 & 86.7 \\
\hline $\begin{array}{l}\text { Made you feel that it was } \\
\text { difficult to carry out your } \\
\text { usual activities? }\end{array}$ & 2 & 0.7 & 1 & 0.4 & 42 & 14.7 & 9 & 3.2 & 231 & 81.1 \\
\hline $\begin{array}{l}\text { Interfered with social } \\
\text { activities? }\end{array}$ & 13 & 4.6 & 1 & 0.4 & 47 & 16.5 & 6 & 2.1 & 218 & 76.5 \\
\hline $\begin{array}{l}\text { Caused you to plan } \\
\text { activities more carefully? }\end{array}$ & 15 & 5.3 & 1 & 0.4 & 33 & 11.6 & 7 & 2.5 & 229 & 80.4 \\
\hline $\begin{array}{l}\text { Caused you } \\
\text { embarrassment? }\end{array}$ & 2 & 0.7 & 1 & 0.4 & 32 & 11.2 & 10 & 3.5 & 240 & 84.2 \\
\hline
\end{tabular}

Table (7): Distribution of studied women according to Health related quality of life energy/ $\mathrm{mood}(\mathrm{n}=\mathbf{2 8 5})$.

\begin{tabular}{|l|c|c|c|c|c|c|c|c|c|c|}
\hline \multirow{2}{*}{\multicolumn{1}{|c|}{ Items }} & \multicolumn{2}{|c|}{$\begin{array}{c}\text { None of the } \\
\text { time }\end{array}$} & \multicolumn{2}{c|}{$\begin{array}{c}\text { A little of } \\
\text { the time }\end{array}$} & \multicolumn{2}{c|}{$\begin{array}{c}\text { Some of the } \\
\text { time }\end{array}$} & \multicolumn{2}{c|}{$\begin{array}{c}\text { Most of the } \\
\text { time }\end{array}$} & \multicolumn{2}{c|}{ All of the time } \\
\cline { 2 - 13 } & $\mathbf{N}$ & \% & $\mathbf{N}$ & \% & N & \% & N & \% & N & \% \\
\hline $\begin{array}{l}\text { Caused you to feel tired or } \\
\text { worn out? }\end{array}$ & 12 & 4.2 & 0 & 0.0 & 19 & 6.7 & 4 & 1.4 & 250 & 87.7 \\
\hline $\begin{array}{l}\text { Caused you to feel drowsy } \\
\text { or sleepy during the day? }\end{array}$ & 4 & 1.4 & 0 & 0.0 & 32 & 11.2 & 9 & 3.2 & 240 & 84.2 \\
\hline $\begin{array}{l}\text { Made you feel sad, } \\
\text { discouraged, or hopeless? }\end{array}$ & 14 & 4.9 & 6 & 2.1 & 29 & 10.2 & 9 & 3.2 & 227 & 79.6 \\
\hline $\begin{array}{l}\text { Made you feel down hearted } \\
\text { and blue? }\end{array}$ & 9 & 3.2 & 5 & 1.8 & 25 & 8.8 & 11 & 3.9 & 235 & 82.5 \\
\hline Made you feel wiped out? & 10 & 3.5 & 5 & 1.8 & 36 & 12.6 & 10 & 3.5 & 224 & 78.6 \\
\hline Made you feel irritable? & 4 & 1.4 & 0 & 0.0 & 25 & 8.8 & 12 & 4.2 & 244 & 85.6 \\
\hline $\begin{array}{l}\text { Made you feel weak as if } \\
\text { energy was drained from } \\
\text { your body? }\end{array}$ & 17 & 6.0 & 0 & 0.0 & 28 & 9.8 & 7 & 2.5 & 233 & 81.8 \\
\hline
\end{tabular}

Table (8): Distribution of studied women according to Health related quality of life control $(\mathrm{n}=285)$.

\begin{tabular}{|l|c|c|c|c|c|c|c|c|c|c|}
\hline \multirow{2}{*}{ Items } & \multicolumn{2}{|c|}{$\begin{array}{c}\text { None of the } \\
\text { time }\end{array}$} & \multicolumn{2}{c|}{$\begin{array}{c}\text { A little of the } \\
\text { time }\end{array}$} & \multicolumn{2}{c|}{$\begin{array}{c}\text { Some of the } \\
\text { time }\end{array}$} & \multicolumn{2}{c|}{$\begin{array}{c}\text { Most of the } \\
\text { time }\end{array}$} & \multicolumn{2}{c|}{ All of the time } \\
\cline { 2 - 12 } & $\mathbf{N}$ & $\%$ & $\mathbf{N}$ & $\%$ & $\mathbf{N}$ & $\%$ & $\mathbf{N}$ & $\%$ & $\mathbf{N}$ & $\%$ \\
\hline $\begin{array}{l}\text { Made you feel as if you are } \\
\text { not in control of your life? }\end{array}$ & 6 & 2.1 & 4 & 1.4 & 23 & 8.1 & 0 & 0.0 & 252 & 88.4 \\
\hline $\begin{array}{l}\text { Made you feel less } \\
\text { productive? }\end{array}$ & 1 & 0.4 & 10 & 3.5 & 29 & 10.2 & 0 & 0.0 & 245 & 86.0 \\
\hline $\begin{array}{l}\text { Caused you to be concerned } \\
\text { or worried about your } \\
\text { health? }\end{array}$ & 4 & 1.4 & 11 & 3.9 & 28 & 9.8 & 5 & 1.8 & 237 & 83.2 \\
\hline $\begin{array}{l}\text { Made you feel uncertain } \\
\text { bout your future? }\end{array}$ & 11 & 3.9 & 10 & 3.5 & 25 & 8.8 & 0 & 0.0 & 239 & 83.9 \\
\hline $\begin{array}{l}\text { Made you feel that you are } \\
\text { not in control of your } \\
\text { health? }\end{array}$ & 12 & 4.2 & 6 & 2.1 & 26 & 9.1 & 0 & 0.0 & 241 & 84.6 \\
\hline
\end{tabular}


Table (9): Distribution of studied women according to Health related quality of life self-conscious ( $n=285)$.

\begin{tabular}{|c|c|c|c|c|c|c|c|c|c|c|}
\hline \multirow[t]{2}{*}{ Items } & \multicolumn{2}{|c|}{$\begin{array}{c}\text { None of the } \\
\text { time }\end{array}$} & \multicolumn{2}{|c|}{$\begin{array}{l}\text { A little of } \\
\text { the time }\end{array}$} & \multicolumn{2}{|c|}{$\begin{array}{c}\text { Some of the } \\
\text { time }\end{array}$} & \multicolumn{2}{|c|}{$\begin{array}{l}\text { Most of } \\
\text { the time }\end{array}$} & \multicolumn{2}{|c|}{ All of the time } \\
\hline & $\mathbf{N}$ & $\%$ & $\mathbf{N}$ & $\%$ & $\mathbf{N}$ & $\%$ & $\mathbf{N}$ & $\%$ & $\mathbf{N}$ & $\%$ \\
\hline $\begin{array}{l}\text { Made you feel self-conscious } \\
\text { of weight gain? }\end{array}$ & 15 & 5.3 & 2 & 0.7 & 34 & 11.9 & 9 & 3.2 & 225 & 78.9 \\
\hline $\begin{array}{l}\text { Made you feel conscious about } \\
\text { the size and appearance of your } \\
\text { stomach? }\end{array}$ & 11 & 3.9 & 6 & 2.1 & 30 & 10.5 & 9 & 3.2 & 229 & 80.4 \\
\hline $\begin{array}{l}\text { Affected the size of clothing } \\
\text { you wear during your periods? }\end{array}$ & 12 & 4.2 & 0 & 0.0 & 23 & 8.1 & 3 & 1.1 & 247 & 86.7 \\
\hline
\end{tabular}

Table (10): Distribution of studied women according to Health related quality of life sexual function ( $n=285)$.

\begin{tabular}{|l|c|c|c|c|c|c|c|c|c|c|}
\hline \multirow{2}{*}{\multicolumn{1}{|c|}{ Items }} & \multicolumn{2}{c|}{$\begin{array}{c}\text { None of the } \\
\text { time }\end{array}$} & \multicolumn{2}{c|}{$\begin{array}{c}\text { A little of } \\
\text { the time }\end{array}$} & \multicolumn{2}{c|}{$\begin{array}{c}\text { Some of the } \\
\text { time }\end{array}$} & \multicolumn{2}{c|}{$\begin{array}{c}\text { Most of } \\
\text { the time }\end{array}$} & \multicolumn{2}{c|}{ All of the time } \\
\cline { 2 - 12 } & $\mathbf{N}$ & $\%$ & $\mathbf{N}$ & $\mathbf{\%}$ & $\mathbf{N}$ & $\%$ & $\mathbf{N}$ & $\%$ & $\mathbf{N}$ & \% \\
\hline $\begin{array}{l}\text { Diminished your sexual } \\
\text { desire? }\end{array}$ & 48 & 16.8 & 3 & 1.1 & 52 & 18.2 & 0 & 0.0 & 182 & 63.9 \\
\hline $\begin{array}{l}\text { Caused you to avoid sexual } \\
\text { relations? }\end{array}$ & 52 & 18.2 & 2 & 0.7 & 53 & 18.6 & 0 & 0.0 & 178 & 62.5 \\
\hline
\end{tabular}

Table (11): Distribution of studied women according to HRQOL among sample females (n=285).

\begin{tabular}{|l|c|c|c|c|c|c|}
\hline \multirow{2}{*}{ QOL domain } & \multicolumn{2}{|c|}{ Poor } & \multicolumn{2}{c|}{ Moderate } & \multicolumn{2}{c|}{ High } \\
\cline { 2 - 7 } & No & \% & No & \% & No & \% \\
\hline Concern & 4 & 1.4 & 24 & 8.4 & 257 & 90.2 \\
\hline Activities & 5 & 1.8 & 43 & 15.1 & 237 & 83.2 \\
\hline Energy & 1 & 4 & 44 & 15.4 & 240 & 84.2 \\
\hline Control & 1 & 4 & 37 & 13.0 & 247 & 86.7 \\
\hline Self-conscious & 19 & 6.7 & 35 & 12.3 & 231 & 81.1 \\
\hline Sexual function & 48 & 16.8 & 56 & 19.6 & 181 & 63.5 \\
\hline
\end{tabular}

Table (1): Shows that, the majority of the sample $(87.4 \%)$ was $\geq 40$ years, with mean score of $47.32 \pm 5.939$ they were mostly coming from rural areas and married $(52.3 \%$ and $81.8 \%)$ More than two thirds $(69.1 \%)$ of them had less than university level of education and $62.5 \%$ were housewives.

Figure (1): Demonstrated that, the majority $(81.8 \%)$ of studied woman had severity of symptoms (severe score $\geq 75 \%$ )

Table (2): Indicates that, about two thirds of the sample (69.1\%) suffered from abnormal menstruation, menorrhagia was the most common (70.8\%), and followed by metrorrhagia and polymenorrhgia $(43.8 \%$ and $22.2 \%)$. Regarding gynecological history $61.1 \%$ of them had gynecological problems ranged from (AUB 35.1\%, dysmenorrhea $30.9 \%$, D \& C $20.0 \%$ respectively). As for parity, more than two fifths $(47.4 \%)$ of the sample had 4 para and more with mean score of $2.29 \pm .757$.

Table (3): Illustrated that, more than half of the studied women $(55.8 \%)$ had $>3+$ years duration of disease with mean score of $3.49 \pm 1.498$, less than half of them $(43.9 \%)$ delayed in having treatment, the common causes of delayed treatment was afraid of treatment and operation (46.4\%), more than one third $(36.8 \%)$ of them was 2 years duration of delayed with mean score of $2.22 \pm 1.023$, and more than two thirds $(64.0 \%)$ of them had excessive bleeding as complications of delay.

Table (4): Illustrated that, severity of symptoms had very great deal in almost subjects regarding heavy bleeding during menstrual period, Fluctuation in the duration of menstrual period compared to previous cycle, Fluctuation in the length of monthly cycle compared to previous cycles and passing blood clots during menstrual period $(93.0 \%, 91.2 \%, 85.3 \%$ and $84.6 \%$ respectively)

Table (5): Shows that, the majority of the study subjects were concerned all of the time regarding soiling underclothes, feel anxious about the unpredictable onset or duration of periods, concerned about soiling outer clothes, feel inconvenienced about always carrying extra pads 
and concerned about soiling bed linen $(88.1 \%$, $87.7 \%, 87.4 \%, 86.3 \%$ and $86.0 \%$ respectively)

Table (6): This table described that, the majority of the study subjects had interfered in their activities as decreased time of exercise, interference with activities, had embarrassment, anxious about traveling, difficult to carry out your usual activities, plan activities more carefully and interference with social activities $(86.7 \%, 85.3 \%, 84.2 \%, 83.9 \%$, $81.1 \%, 80.4 \%$, and $76.5 \%$ respectively).

Table (7): This table described that, the majority of the study subjects had interfered in their life energy/ mood as caused you to feel tired or worn out?, made you feel irritable?, caused you to feel drowsy or sleepy during the day?, made you feel down hearted and blue?, made you feel weak as if energy was drained from your body?, made you feel sad, discouraged, or hopeless? and made you feel wiped out? $(87.7 \%, 85.6 \%, 84.2 \%, 82.5 \%, 81.8 \%$, $79.6 \%$ and $78.6 \%$ respectively)

Table (8): Illustrated that, the study subjects had interfered in their control, made you feel as if you are not in control of your life?, made you feel less productive?, made you feel that you are not in control of your health?, made you feel uncertain about your future? and caused you to be concerned or worried about your health? $(88.4 \%, 86.0 \%$, $84.6 \%, 83.9$ and $83.2 \%$ respectively)

Table (9): Illustrated that, the study subjects had interfered in their self-conscious, affected the size of clothing you wear during your periods?, made you feel conscious about the size and appearance of your stomach? and made you feel self-conscious of weight gain? $(86.7 \%, 88.4 \%$, and $78.9 \%$ respectively)

Table (10): This table described that, more than two thirds of the study sample was diminished your sexual desire? $63.9 \%$ and $62.5 \%$ of the study sample caused you to avoid sexual relations?

Table (11) Demonstrated that, studied woman had negative impact on HRQOL concern, control , energy, activities, self-conscious and sexual function $(90.2 \%, 86.7 \%, 84.2 \%, 83.2 \%, \quad 81.1 \%$ and $63.5 \%)($ severe score $\geq 75 \%)$

\section{Discussion}

Uterine fibroid or uterine leiomyoma is a common reason for gynecological consultation in most hospitals as well as the most common benign genital tract tumor which are associated with sub-fertility and early pregnancy loss in women of reproductive age (Momen et al., 2017). Women's HRQOL and well-being, including daily physical and social activities, are known to be negatively affected by the symptoms of uterine leiomyoma (Borah et al., 2014).
According to a 2010 World Health Organization report, uterine fibroids affects between $20-25 \%$ of women, (Atombosoba et al., 2018).Treatment of this condition has undergone a significant transformation in recent years (Munro, 2007). Novel and more efficient drugs have been developed to treat symptomatic UL. However, surgical procedures are still highly prevalent in some countries to treat UL. UL are the main reason for performing hysterectomies (Farquhar et al., 2002). In our study mostly indications for hysterectomy were uterine myoma (Mohamed Elessawy, 2013).

The total US cost from $\$ 5.9$ billion to $\$ 34.4$ billion annually It is known that UL causes abnormal uterine bleeding and pelvic pressure or pelvic pain as main symptoms, impairing women's' health related quality of life (Borah et al., 2014). Which is affected by many factors such as; symptom severity, concern, activities, energy, control, self-conscious and sexual function. However, this last parameter was the object of fewer researches (Williams et al., 2006). Therefore the present study was conducted to assess the effect of uterine fibroid on women health related quality of life and evaluate the impact of management program for patients undergoing hysterectomy on their quality of life.

Socio-demographic factors appear to influence women health related quality of life. About half of the subjects were aged 50-55 years with the mean score of $47.3 \pm 5.9$ and about half of them resided in rural areas. The majority was married and about two thirds of them were house wives. This was similar to Lígia Flávia, (2012) in Portugal who reported that most women had UL between 40 and 59 years and Borah et al., (2014) study in UAS who found that about $70-80 \%$ of the study subject women aged 50 years. Furthermore, Brito et al., (2016) in Brazil found that, the mean age of the subjects was $46.6 \pm$ 6.5 years.

Abdallah \& Gomaa, (2013) study in Saudi Arabia found that UL was mostly common among women in age groups between 41-50 years. Recently Momen et al., (2017) study in Egypt found that about half of women with UL were found in age group between 30-35 years. Also Mohammed Abdelsalam, (2017) reported that highest incidence of uterine fibroid was in the age group 36-40 years. Borah et al., (2013) found that the majority of respondents were married. This discrepancy between the previous studies was due to the differences in study design, and the criteria of selection of the sample as well as women profile. Therefore, age is the critical determinant of reproductive outcome in women with fibroids (Casini et al., 2006).

As for the level of education the present study showed that more than two thirds of subjects had 
less than university level of education and were housewives and in fact this reflect nothing more than actual distribution. This coincides with Lígia Flávia, (2012) who reported that about two thirds of LU women had an education level of high-school. Moreover, Mohammed Abdelsalam, (2017) found that more than two thirds of the study groups were unemployed. While Brito et al., (2014) found that more than half were employed.

The present study finding showed that more than two thirds of subjects suffered from menorrhagia. Incongruence, with these studies Pramod Philip Nittala and Roshni Shukla, (2013) and Momen et al., (2017) found that menorrhagia was the most clinical presentation in women with uterine fibroids .Also, Carolyn et al., (2009) was described uterine fibroids signs and symptoms as follows: Abnormal uterine bleeding with longer, heavier menstrual periods. While Mohammed Abdelsalam, (2017) found that menorrhagia was present in only one third of his study subjects. This difference could be related to the size and location of uterine fibroids among the study subjects.

The current study result indicates that more than one third of subjects suffered from metrorrhagia. In contrast, Carolyn et al., (2009) were described uterine fibroids signs and symptom as follow bleeding between menstrual periods occur. Here data are difficult to compare due to differences in the study population and screening methods.

Moreover, Lígia Flávia, (2012) in Portugal reported that metrorrhagia was present in two thirds of the study subjects. Borah et al., (2014) study reported that nearly one third of women characterized their cycles as uterine bleeding at irregular interval particularly between the expected menstrual periods similar to the finding of the present study.

This study revealed that two thirds of the sample suffered from abnormal menstruation, which agrees with finding of Borah et al., (2014) who found that abnormal menstrual cycle was present in half of the study subjects and Brito et al., (2016) who mentioned that abnormal menstruation was the most prevalent sign. On the other hand, one third of the studied women had dysmenorrhea this partially similar with Pramod Philip Nittala \& Roshni Shukla, (2013) \& Abdullah \& Gomaa, (2013).

The present study finding that fibroids were mostly prevalent in multiparas group ( $\geq 4$ para) this agree with Borah et al., (2014), Momen et al., (2017) and Mohammed Abdelsalam, (2017) who found that the majority of their study subjects were multiparas. In contrast Ezeama et al., (2012) found that about two thirds of the study subjects were nulliparous. This difference persisted even after accounting for potential confounding due to differences of baseline characteristics.

Infertility was found among $4.2 \%$ of the study subjects following the same line as in other studies. Osman, (2010) study in Gazera state reported 5.5\% incidence of infertility in 200 studied women with UF. Also, Bendifallah et al., \& (2011), Pramod Philip Nittala and Roshni Shukla, (2013) \& Abdullah \& Gomaa, (2013) estimated that fibroids may be associated with infertility in 5 to $10 \%$ of cases. Moreover, Mohammed Abdelsalam, (2017) showed that infertility was $6.5 \%$.

According to Borah et al., (2014) the mean amount of time to seek treatment for all women in the survey was 3.6 years, while the median wait time for seeking treatment was 2 years and one quarter of women sought treatment within the first year of experiencing symptoms. This is similar to the present study finding except that more than half of women sought treatment within the first year of experiencing symptoms. Moreover, Brito et al., (2014) lack of knowledge of the actual physiopathology of the disease may influence the treatment decision-making process therefore; it is worrisome that women do not have adequate knowledge to make the right decision.

They added that the most reported fears, including being afraid that their UL will grow, there is something inside of them that doesn't belong there, they would experience future health complications, will need a hysterectomy, the UL would turn into cancer, or that the UL would affect their sex life. This is partially in agreement with the present study finding regarding the causes of delay in treatment in addition to hoping for pregnancy, financial problems and lack of knowledge about disease and treatment which may influence the treatment decision-making process taken by the woman. Here comes the indispensable role of the maternity nurse in alleviating women's fear and clearing up misconceptions.

Most women preferred noninvasive options for treatment irrespective of the desire for childbearing. A considerable number of hysterectomies occur each year in the United States, with substantial costs for the health care system. Despite the curative effect of hysterectomy for UL, the long-lasting health impact of hysterectomy, even with ovarian conservation, is not completely understood (Hartmann et al., 2006) and (Wechter et al., 2011).

Observational study showed that UF had a negative impact on the women's quality of life. They presented social and professional limitations with fear, disbelief and despondency regarding their symptoms, and these factors strengthened their will 
to undergo hysterectomy. Thus, the impact of UF symptoms on women's health-related quality of life (HRQL) is a major indicator for treatment (Harding et al., 2008) \& (Brito et al., 2014).

The current study revealed that, women with UF presented worse quality of life when analyzed by means of the SF-36 questionnaire. This may indicate that the UFS-QOL questionnaire is fulfilling its task of targeting women with UF. These data are similar to what was found in the validation studies conducted by (Spies et al., 2002, Harding et al., 2008 \& Coyen et al., 2012).

As regards HRQOL, symptom severity showed the highest mean score among all factors in the health related quality of life scale. This result was supported by Karin et al., (2012) and Brito et al., (2016). The highest concern was about the feeling of anxiety and soiling underclothes as well as interference with physical or social activities thus causing women embarrassment. This result is supported by Brito et al., (2016)

Furthermore, in agreement with Brito et al., (2016) most of them were exposed to the feeling of tiredness, drowsiness, irritability as well as they had the feeling of no control of health or life and being less productive. They also were anxious about the change in their body image due to the increase of the size and appearance of their stomach. In addition to the feeling lack of sexual desire .The above mention findings are in agreement with Borah et al., (2014) and Mohamed Elessawy, (2013) study at Holstein, who found that the symptoms of women with UF strongly correlated with lower HRQL subscales and higher severity symptoms scores.

\section{Conclusion}

Based on the finding of the present study it concluded that: severity of symptoms had very great deal in almost subjects in the present study. Fibroids impact negatively on women's health and quality of life.

\section{Recommendations}

Based on the finding of the present study it recomended that

$\checkmark$ Women should be provided with simple information (through brochures and booklets) that can consist of health education about uterine fibroid.

$\checkmark$ Replication of the study on nurses to improve their awareness, health practices and beliefs regarding the prevention and early detection of uterine fibroid, which will be reflected in improving women's awareness, health practices and beliefs.

$\checkmark$ Screening programs with high coverage of the "at risk" group for reducing the number of new cases with fibroid and the decrease the mortality rate associated with it.

\section{References}

1. Abdullah L., \& Gomaa W., (2013): The Clinicopathological Characteristics of Uterine Leiomyoma: A Tertiary Care Centre Experience in Saudi Arabia. Rep Opinion; 5(10):21-26]. (ISSN:

1553-9873). http://www.sciencepub.net/report.

2. Angelos G., Vilos, Catherine Allaire, PhilippeYves Laberge \& Nicholas Ley l., (2015): The Management of Uterine Leiomyomas. J Obstet Gynaecol Can; 37(2):157-178.

3. Atombosoba A., Ekine, Lucky O., Lawani, Chukwuemeka A., Iyoke, Bonafede M., Pohlman S., Miller J., Thiel E., Troeger K., \& Miller C., (2018): Women with newly diagnosed uterine fibroids: treatment patterns and cost comparison for select treatment options. Popul Health Manag; 21:S13-20.

4. Bendifallah S., Brun J., Fernandez H., Bonafede M., Pohlman S., Miller J., Thiel E., Troeger K., \& Miller C., (2018): Women with newly diagnosed uterine fibroids: treatment patterns and cost comparison for select treatment options. Popul Health Manag; 21:S13-20.

5. Borah B., Nicholson W., Bradley L., \& Stewart E., (2014): The impact of uterine leiomyomas: a national survey of affected women. Am J Obstet Gynecol; [PMC free article] October 01; 209(4): 319. doi:10.1016/j.ajog.2013.07.017.

6. Brito L., Panobianco M., Sabino-de-Freitas M., Barbosa Hde F., de \& Azevedo G., (2014): Uterine leiomyoma: understanding the impact of symptoms on womens' lives. Reproductive Health 11:10 http://www.reproductive health journal.com.

7. Brito L., Malzone-Lott D., Fagundes M., Magnani P., Arouca M., Poli-Neto O., \& Nogueira A., (2016): Translation and validation of the Uterine Fibroid Symptom and Quality of Life (UFS-QOL) questionnaire for the Brazilian Portuguese language. DOI: 10.1590/15163180.2016.0223281016. Sao Paulo Med J. 2017; 135(2):107-15

8. Carolyn J., Hildreth, Cassio Lynm, M., \& Richard M Glass. (2009): Uterine fibroids F. Jama J.; 301 (1): 122.

9. Casini M., Rossi F., Agostini R., \& Unfer V., (2006): Effects of position of fibroids on fertility. Gynecol Endocrinol, 22(2): 106-109.

10. Clarke-Pearson D., \& Geller E., (2013): Complications of hysterectomy. ObstetGynecol. Mar; 121(3):654- 
73.doi:10.1097/AOG.

https://www.ncbi.nlm.nih.gov/pubmed/23635631

11. Coyne K., Margolis M., \& Bradley L., (2012): Further validation of the uterine fibroid symptom and quality-of-life questionnaire. Value Health (1):135-42.

12. Donnez J., \& Dolmans M., (2016): Uterine fibroid management: from the present to the future. Hum Reprod Update. ; 22(6):665-86. 10.1093/humupd/dmw023 [PubMed free article]

13. Ezeama C., Ikechebelu J., Obiechina N., \& Ezeama N., (2012): Clinical Presentation of Uterine Fibroids in Nnewi, Nigeria: A 5-year Review. Ann Med Health Sci Res, 2(2): 114-118.

14. Farquhar C., Naoom S., \& Steiner C., (2002): The impact of endometrial ablation on hysterectomy rates in women with benign uterine conditions in the United States. Int $\mathbf{J}$ Technol Assess Health Care, 18:625-34.

15. Harding G., Coyne K., \& Thompson C., (2008): The responsiveness of the uterine fibroid symptom and health-related quality of life questionnaire (UFS-QOL). Health Qual Life Outcomes; 6:99

16. Hartmann K., Birnbaum H., \& Ben-Hamadi R., (2006): Annual costs associated with diagnosis of uterine leiomyomata. Obstetrics and gynecology; 108:930-937. [PubMed: 17012456]

17. Karin S., Coyne, Mary Kay Margolis, Linda D., Bradley, Richard Guido, G., Larry Maxwell \& James B., Spies. (2012): Further Validation of the Uterine Fibroid Symptom and Quality-of-Life Questionnaire. journal homepage: www.elsevier.com/locate/jval. Published by Elsevier Inc.

18. Lígia Flávia da Silva Barbosa. (2012): Epidemiological factors associated with Uterine Fibroids UNIVERSIDADE DA BEIRA INTERIOR Ciências da Saúde.

19. Mayo Clinic Science Daily. (2019): Uterine fibroids have significant impact on quality of life, workplace performance. https://www.sciencedaily.com /releases/10/131024085836.htm accessed at $1 / 2019$

20. Mohamed Elessawy, (2013): hysterectomy, a comparative study of the different hysterectomy routes 2002- 2010 a retrospective analysis for 954 patients

21. Mohammed Abdelsalam Ahmed Abdelmotalab, (2017): Anatomical Locations \& Types of Uterine Fibroids and their Impact on the Clinical Presentation. Clin Obstet \& Gynecol

22. Momen A., Kamel, Ahmed M., Nasr, Kamal M., Zahran \& Sohir A., Ibrahim, (2017):
Reproductive Performance in Women with Fibroid. American Journal of Medicine and Medical Sciences (12): 393-399. Momen: The Role of Surgery. J Gynecol Obstet Biol Reprod.; 40 (8): 885901.

23. Munro M., (2007): Management of heavy menstrual bleeding: is hysterectomy the radical mastectomy of gynecology? Clin Obstet \& Gynecol, 50:324-53.

24. Osman A., (2010): Etiology of Female Infertility in Gezera (Central Sudan). Jornal of Applied Science; 10 (19) 2333-2337.

25. Pramod Philip Nittala \& Roshni Shukla. (2013): Cystic Degeneration of Uterine Fibroid Mimicking A malignant Uterine Neoplasm on MRI. International Journal of Medicine.; 1 (1): 13.

26. Soliman A., Margolis M., Castelli Haley J., Fuldeore M., Owens C., \& Coyne K., (2017): Impact of uterine fibroid symptoms on health related quality of life of US women: evidence from a cross-sectional survey. Curr Med Res Opin., 33(11).

27. Sparic R., Mirkovic L., Malvasi A., \& Tinelli A., (2016): Epidemiology of uterine myomas: a review. International Journal of Fertility and Sterility; Vol 9, No 4, Jan-Mar, Pages: 424-435

28. Torb E., Crawford R., Nordin A., \& Acheson N., (2013): Enhanced recovery in gynaecology. The Obstetrician and Gynaecologist; 15:263-8.

29. Wechter ME, Stewart EA, Myers ER, Kho RM and Wu JM. (2011): Leiomyoma-related hospitalization and surgery: prevalence and predicted growth based on population trends. Am J Obstet Gynecol;205:492.e1-5.

30. Williams V., Jones G., Muskopf J., Spalding J., \& DuChane J., (2006): Uterine fibroids: a review of health-related quality of life assessment. J Womens Health, 15:818-29.

31. Zimmermann A., Bernuit D., Gerlinger C., Schaefers M., \& Geppert K., (2012): Prevalence, symptoms and management of uterine fibroids: an international internet-based survey of 21,746 women. BMC women's health. 12:16. [PubMed: 22727195] March). Available at: http://www.biomedcentral.com/1472-6874/12/6. Accessed on November 10, 2014. 